\title{
Social Facts, Moral Regulation and Statistical Jurisdiction: A Critical Evaluation of Canadian Census Figures on Education
}

\author{
SHMUEL SHAMAI* and
}

PHILIP R. D. CORRIGAN**

\begin{abstract}
After a brief general consideration of the census, state-formation and moral regulation, together with the use and abuse of this form of 'numbering the people', two major illustrative examples are provided which expose the problematic nature of seemingly objective censal data: illiteracy and ethnicity in the Canadian Censuses of 1921 and 1981 particularly. The bulk of the paper consists of an examination of the trends in ethnicity and gender in relation to varying measures of educational achievement in the Canadian Census 1921 through 1981. The summarised findings are that two of the three 'founding peoples' ('British' and 'French') are located in the middle range, whilst the third ('Native peoples') is located at the bottom; all other ethnic groups are more polarised. This is a consistent pattern across the sixty years surveyed, although it is often (in popular and academic writing) treated as a 'new phenomenon'. With regard to gender, the paper qualifies the popular myth that the education system is now less gender ascriptive than it was previously: wherever females have been better than males, the males have tended to close the gap or even reverse the situation; wherever males have been better than females, the gap has closed slowly, if at all. This confirms the recent study by Pineo and Goyder, based on the 1981 census alone, that "the Canadian educational system acts more ascriptively upon women than on men." For all the problems of Census data, the article argues that it can be used to discern aggregate trends over time which qualify many contemporary myths.
\end{abstract}

\section{RÉSUMÉ}

Un bref examen du recensement en général, de la composition du pays et des règles morales, ainsi qu' une étude de l'usage normal et abusif de cette manière de "compter le peuple" ont permis de mettre en évidence deux principaux problèmes

*Research Officer, Golan Institute, Katzerin, Israel.

**Professor, Department of Sociology in Education, Ontario Institute of Studies in Education. 
que cachent des données de recensement apparemment objectives. Il s'agit de l'analphabétisme et de l'appartenance ethnique dans les recensements canadiens de 1921 et 1981 en particulier. Dans l'ensemble, l'article traite des tendances ethniques et par sexe par rapport aux diverses réalisations dans le domaine de l'éducation révélées par Recensement Canada de 1921 à 1981. En résumé, on conclut que deux des trois peuples "fondateurs" (les Anglais et les Français) se situent dans la moyenne alors que le troisième (les Améridiens) est au bas de l'échelle. Ce modèle s'est répété constamment pendant les soixante années étudiées, bien que souvent (dans les publications communes et savantes) on qualifie ce phénomène de "nouveau". En ce qui concerne le sexe des étudiants, l'article!nuance! le mythe populaire qui veut que le système d'éducation favorise moins un certain sexe qu'il ne le faisait auparavant. Lorsque les femmes réussissent mieux que les hommes, les hommes ont tendance à rattraper le retard ou même à renverser la situation ; par contre, lorsque les hommes réussissent mieux que les femmes, l'écart se comble lentement, si jamais il se comble. Cette observation confirme les résultats de l'étude menée par Pineo et Goyder, basée sur le recensement de 1981, qui montre que le "système d'éducation canadien a un effet plus statique sur les femmes que pour les hommes". Devant tous les problèmes que présentent les données de recensement, l'article soutient qu'on peut les utiliser pour discerner les tendances générales dans le temps qui s'appliquent également à bien des mythes contemporains.

\section{Introduction}

This paper explores biases in educational data collected by Statistics Canada, and in particular, its relationship to ethnicity. The Census data seems to be very "neutral", "objective" and "without any bias"; however, as will be shown here, such is not the case. The social implications for any given data can be very significant, particularly when the data is collected under the auspices of the official government (of Canada or any state) for planning purposes. The paper will also point to social facts behind the public data, mainly to discuss the educational achievement gap among some ethnic groups.

Censuses and Statistics have been collected under the authority of the State from early history. When King David numbered the people of Israel and Judah, about three thousand years ago, he realized that he was undermining God's authority, according to the Bible. Thus "David's heart smote him after that he had numbered the people. And David said unto the Lord, I have sinned greatly in that I have done: and now, I beseech thee, O Lord, take away the iniquity of thy servant; for I have done very foolishly" (Samuel II, 24: 10). The punishment, according to the Bible, was very severe indeed: seventy-seven thousand people of Israel died in a plague that followed this census. Nevertheless, rulers and state authorities have continued to practice their power and control by counting 'their' people. 
Moreover, the changes in the terminology and claimed authority are indicators of the state formation process. Moving from the surveys of conquest (such as the Domesday Book of 1086) through the determination of who are 'our subjects' (such as the Parish Registers established in England in 1538) to 'numbering the people' and 'political arithmetic', are all procedures of State Formation. The term Statistics is derived from the word State (Webster New World Dictionary, 1980: 1391) and the formation of statistical organizations has been part of the state formation of the modern nation-state. For example, although in Great Britain, from 1830, different Statistical Societies and organizations were established (Cullen, 1975) by the mid-nineteenth century " 'the State' had successfully secured a monopoly over the legitimate right to collect a range of statistical information" (Corrigan and Sayer, 1985: 135). This 'Right' is, in most states enshrined in law: citizens/subjects cannot refuse to complete forms or to supply data demanded by the State (cf. Canadian Census, 1986: Guide-book for households).

Like all 'social facts' they have deep moral regulatory features: (Durkheim, 1912:20). Statistics need to be recognized in terms of the jurisdiction of state formation, like maps and surveys of property they establish and confirm proper social norms and forms (Corrigan, 1981; Corrigan and Sayer, 1985, 1987; Henriques, 1984). They also render many historical experiences invisible, or at least marginal because improper (eg the so-called "non standard family", Williams, 1986; the "immigrant", Ng and Estable, 1987). Statistics, are abstractions (Sayer, 1987) that 'document' reality into a particular social organization of social knowledge (Smith, 1987).

\section{Use and abuse of numbers}

Statistical abuse or misuse is a common occurrence even in sociological and educational studies, as has been made evident from the critical probing of the Radical Statistics Education Group (1982). Moreover, it occurs in Census data too. Hakim (1980) examined the prefaces (or commentaries) that were part of the Census Reports in Britain and in the United States. A somewhat similar methodology applied to Canada, allows the commentaries to become a main source of information. Hakim pointed out that the modern census and its commentaries "are also a source of information on how the population census is adapted and modified to answer questions of the day; that is, they reveal the census as a social product" (p. 570). As a result "the commentaries could thus be more extensively used as a source of information on the social and cultural context in which the statistics were produced" (p. 573).

Where any census data is used there is a need to be very cautious. There are many biases and mistakes possible in different stages of processing the data. Each of the steps, from preparing the questions and categories that 'produce' the data, to the final publication (or concealment in some cases), is very subjective. The first stage is the decision about what is and what is not relevant to be surveyed. The following stage is the wording of the question and the variable's definition. The 
next step is enumeration which depends on reliable and careful instructions given to the enumerated and on their "good will" in following the exact instructions. Eliciting the 'right' answer also depends on the interests and beliefs of the respondents. ${ }^{1}$ The following step of deciding how to classify and code the data and particularly the categories of "others", "missing data", or data that can not be fitted to any categories can be very subjective. Another problem is the lack of data comparability between and among the censuses. This problem occurs even between two consecutive censuses: for example, Statistics Canada had to publish a special "Technical Working Paper" (Demeres and Karlt, 1984) to deal "with the changes in the processing of the 1976 and 1981 mother tongue" data (p. 9). Moreover, "theoretically, the mother tongue data from 1941 to 1981 should be directly comparable. However, this is not the case. Data comparability from census to census is affected by many factors, some due to changes in census methodology and some due to changes in society external to the census" (ibid). The comparability problems can also be exemplified in regard to education and ethnicity (or 'racial origin') variables which have been reported in the censuses from 1921 to 1981 . The 1921 and 1931 Censuses' data categorize "Illiteracy", classified according to racial origin. In 1931 only, there is information about school attendance and racial origin (1931, V.1, Table 74). In 1941 only, there is an "Index of school attendance" for population 5-19 years of age, by racial origin. The 1951 census data concerns the population 5 years of age and over attending (and not attending) school, by years of schooling and origin. The 1961 official published Census data is lacking this information, but the 1961 unpublished Census information gives levels of schooling and ethnic groups. The 1971 and the 1981 Census profiles the population 15 years and over attending school, and separates out information about the population 15 years and over not attending school, by ethnic origin, showing the highest level of schooling.

In addition to the comparability problems and problems within each census that have just been described, data presentation, an area which is the focus of this section, can be problematic. The abuse of the census data through presentations of data that are being made, the ways these presentations are conceived, the categories chosen to be presented, the data that is not presented, and the categories that are missing are all very selective. The early Censuses were more explicit than the more current Censuses; thus it is easier to expose their intentions. The Canadian Censuses since 1951 have become less "verbal" and have supplied fewer interpretations, so the meaning behind the data is more implicit. (Similarly, in the United States of America and Britain the commentaries ceased to appear after the 1951 Census, Hakim, 1980: 551, 571). The 1931 census of Canada, however, elaborates many details about the Census findings, and these details provide clear insights about very important questions regarding the motives and ideology behind the data.

It is usually difficult to point out if and how official statistics, including Statistics Canada, use their power. Like Foucault $(1981 ; 1982)$ we believe power 
is never more powerful when it is rendered relatively invisible in seemingly 'descriptive facts' produced by 'neutral institutions'.

There are major flaws that have been indicated, like the persistent changes in the variables and categories analyzed from one Census to another, and as Hakim (1980) states, "the definitional change will necessarily distort or obscure the picture presented of changing social reality being observed" (p. 571). While Hakim (1980) points to the way the British and American censuses miscategorized and misrepresented women, Williams (1986) and Armstrong and Armstrong (1983) point to a similar situation in the Canadian Censuses:

We have argued that, like all methodologies, those of Statistics Canada reflect a perspective, one that better serves the interests of men and the economy than those of women and the home.... The priorities of the agency thus allow only a partial, and sometimes distorted, view of woman's work. ... The way data are collected and tabulated, the way questions are asked and not asked, the way government programmes and policies are structured and the way in which history is considered, all influence the data and in process often leave out and sometimes misrepresent the position of woman (Armstrong and Armstrong, 1983: $36-37) .^{2}$

Clearly, the Census biases are not only part of the past but are still very much a part of the present. The 1986 Census again fueled debate and criticism in Quebec. Professor C. Castonguay, a mathematician, criticizes the 1981 and 1986 census for "the way Statistics Canada asks some of its census questions, the way it later presents the answers and the way some other people interpret these findings" (Toronto Star, 29 May, 1986: A18). His conclusion is that the biases favour the English speaking population's political needs and discriminate against the French speaking population in Quebec. These current controversies are part of an historical legacy of biased presentation as is manifested in the following two sections, which focus on "illiteracy" and education, and on ethnicity.

\subsection{Data representation and social order: "illiteracy" and the Census}

The 1931 Census figures illustrate very dramatically the moral regulation accomplished by the Census presentations; the guidelines whose focus on "ethnicity" provide an important tool to divide and control, and not a simple "objective" criteria. This moral jurisdiction (literally speaking the law) which was manifested in the 1931 Census' elaborate discussions about education are presented in this paper as blunt and very crude evidence of this bias, as an example of how 'typification' is a form of such an abstraction.

Interestingly, there are two discussions about literacy and "illiteracy" in the 1931 census, a short one (V.1; p. 79) and very elaborate one (V.12; "Illiteracy" and "School Attendance" which includes 10 chapters and over 170 pages!). The latter discussion will be analyzed here. From the outset "illiteracy" is defined as a "negative term" (p. 581). According to the Census explanation, race (including place of birth) is the chief factor determining the "illiteracy" of Canadians. 
"Illiteracy" for the individual is "disability and what the country loses through his ${ }^{3}$ lack of intelligent grasp of the duties of the citizen because ignorant of letters" ( $p$. 582). The "illiterates" are not only a passive loss to the country but there is a "possibility and even ... probability that they are anti-social due to the fact that they are earning less than the literate population and at the same time they are willing to assume responsibilities which they are poorly equipped or unable to meet" (p. 583) (emphasis added). The Census provides a list of 11 attributes for which "illiterates" were tested and found to be "below" the literates (for example: "... tendency to different marital status; ... tendency to have larger families; ... lower earnings; ... show more illegitimacy; ... show definitely a greater proportion of inmates in mental institutions; ... show ... a greater proportion, especially of females, in corrective institutions (p. 583) (underlining added). Moreover, this Census' commentary states that "the information on illiteracy [gives] the opportunity of designating the [lower/working] class" (p. 583). Similar concerns also existed in regard to the 1921 census figures. The commentary stated that "illiteracy" "cannot but be a matter of grave concern for those who are interested in the development of an enlightened Canadian people" (Statistics Canada, 1929: 170). Here is one example of how typifications are stereotypes (Perkins, 1979).

There is no doubt that the 1931 Census evaluates the results according to a "moral code" that contains a specific set of values. This is very apparent in its "family moral code" but it is much more blunt in regard to the population of mental and penal institutions. Without any explanation as to why, the definition of "illiteracy" is changed when the Census deals with inmates of mental institutions. The new definition includes all people who cannot write or cannot read, in contrast to all the other groups in which a "literate" is a person who can either read or write. Thus, for example, a non-institutionalized person who can read and can not write, will be classified as a literate, but once the same person becomes an inmate he/she will be classified as an illiterate. Not surprisingly, when the Census compares the "illiteracy" rates of the "general population" and the inmates of mental institutions it finds relatively more "illiterates" among the inmates (Table XLI, p. 637) with only a short footnote that refers to the different definitions. However, the discussion fails to mention this difference!

After 'proving' and pointing to the connection between different "immoral" attributes and "illiteracy" the Census data and commentary indicate a deviation or contradiction in their own argument. The comparison between criminals (or inmates of penal institutions) and the "general population" leads to the interesting conclusion: "there seems to be no great connection between illiteracy ... and crime" (p. 638). The Census explanation is that the "inmates of penal institutions are not illiterate because some of them are taught to read after being committed" (p. 638). However, the most striking data is that while the percentage of "illiteracy" for the total Canadian population 15 years and over is 4.72 the comparable percentage among the convicted persons is only 1.70 ! (significantly less). These figures are less surprising than the Census explanation and conclusion: 
Among these no serious-minded person should include the likelihood that criminals are more clever than others. The mere fact of being able to read and write is no great indication of cleverness. The number of "illiterates" being cared for in mental and other institutions leaves less for criminal institutions.

This conclusion suggests that several of the "illiterates" in mental institutions are in fact criminals! It further suggests that literacy is not a serious indication of cleverness, in contradiction to all their previous discourse. These contradicting features of official discourse are quite common (Donald, 1979).

Manipulation of the data can arise when any decision is made as to how and what to present and publish. One evidential example can be drawn from the statement that "illiteracy is definitely greater among males than among females" (1931 census, V.1 p. 79), while, in the elaborate discussion of V.12, the conclusion is reversed - the sex difference is "so small that it is practically negligible" (V.12, p. 58). After complicated data manipulations the conclusion is "there is practically no difference in "illiteracy" between males and females" (V.12, p. 600). In the 1921 Census it was found that among the population 10 years of age and over, that females were less "illiterate" than males ( 5.17 percent males "illiterate", while there were only 3.75 percent females "illiterate"; 1921 Census: V.2, Tab. 98). However, the Census again pointed to other explanations for this gap (age, nativity, origin, etc.) and concluded: "illiteracy is thus not a sex differentiation" (Statistics Canada, 1929: 174).

A selective and biased way of presentation and interpretation is apparent also in the representation of racial origin and education, in statistical classifications. In regard to the school attendance category, the classification discussed and explained is according to the "nativity' of the respondent ("Canadian born" or "British born" or "Foreign born") ${ }^{4}$ which points to the British born as the leading group ("class"). "The British born attend school more regularly than do either of the other two classes (1931 Census, V. 12, p. 584), and further, "The Foreign born apparently are behind the other two classes" (p. 651). There is no mention, however, of the way school attendance varies according to different "racial origins". According to the Census figures gathered, but not according to the data profiles released, "the Jews" are the leading group; they and the "Belgian" group have relatively more students than the "British races" in the longest period of school attendance.

A similar sort of presentation is apparent in regard to "illiteracy" rates. This time the discussion does not fail to present the racial origin category; moreover, this discussion even classifies the racial origin groups "in descending order of 'illiteracy' rate" (1931 Census, V. 12, Table II, p. 595). Again there are those who are being excluded. According to a footnote, the numbers include only the nine provinces (excluding the Territories). The total of Canadian "illiterates" numbered 304,513 people (out of 8,159,059 Canadians). In V.4. Table 10, the total Canadian "illiterates" were 272,791 people out of 8,074,753 Canadians. This time the Territories are excluded, and also all "Indians" in the provinces. The real (?) number of "illiterates" is 309,396 people out of 10,367,786 Canadians (V.4, 
Table 63). When the "Indian and Eskimo" are added to the V.12 discussion they have by far the highest percentage of illiterates (37.61)! At the other extreme are the "other British" (Welsh?) (0.41 percent) followed by Scottish and English (both 0.83 percent) and Irish (1.08). Then the Census classifies the racial origin groups in four "steps". The first "step" with the lowest "illiteracy" rate includes the "other British", Scottish and English. The second includes, among others, "the Irish" and "the Jews", while the last one includes the "Slavs, Latins and Coloured" (V. 12, p. 596). This presentation which favours very much the "British races" is the only presentation in regard to racial origin and illiteracy. While about 86 percent of the population is Canadian born there is no ranking for this specific sub-group ${ }^{5}$. If the "illiteracy" of Canadian born had been presented the numbers would have been much different. The "Icelandic" and "the Jews", followed by the "Czech and Slovak" and the "Finnish" groups, would have been the leading groups and the "Chinese" would have been closer to the center (and not the second to the last as they are in the total population). The "British races" would have been in a "good position" but not in the "best position". In fact there is an elaborate discussion about 'nativity' and the improvement according to 'races' and 'nativity'. However, the Census concludes: "It would be interesting to measure the improvement (or the contrary) to the general "illiteracy" due to changes in racial distribution, but it seems hardly worthwhile making this calculation, especially as this improvement is tangled up with sex, nativity and age distribution" (V.12 p. 619) (emphasis added). As was mentioned before, the most positive change would favour "the Jews", and the change among the "British races" would be the reverse! Is it surprising that this kind of tabulation is "hardly worthwhile"? "Worthwhile" for whom?

In contrast to not calculating the racial origin of Canadian born "illiterates" there is another interesting calculation that was carried out: "Illiteracy of other races compared with that of British races" (Table IV, p. 599). The table results, as expected, manifest a total superiority of the "British Races" over the "others". As mentioned above, a different presentation of the data would have reached different conclusions.

Similar presentations and omissions are also evident in regard to the 1921 Census figures. Moreover, the 1921 figures of "illiteracy" are compared with the "inability to speak English and French". Not surprisingly it is found that "there is a very definite relationship" between these two variables (Statistics Canada, 1929: 174).

The impressions from the section about the education indicators (school attendance and illiteracy) is that the presentation of the data, and the omission of data, serve the purpose of reinforcing the "British races" superiority (almost as a "chosen people" phenomenon), while lumping together all the non-British groups, as "inferior races". This method of presentation is similar to other presentations that have been reviewed here. "The Jews" are one of the groups that have been excluded, much as other subordinate groups are being ignored, or stereotyped. The best way to deal with the data is to analyze it according to the specific study 
needs. However, even the use of the available data may be limited as any step from the phrasing the question to the final presentation is open to biased interpretations, a striking cautionary reminder because the official figures of Statistics Canada usually seem to be "objective" and "innocent".

\subsection{Data representations and social regulation: Ethnicity and the Census}

Probing the data about Census 'collective misrepresentations' (Abrams, 1977) can provide other examples of biased data manipulation. The official definition of ethnicity can supply an important indicator of the Census biases. The definition of ethnicity (based on the question regarding ethnicity) in the 1981 Canadian Census is: "the ethnic or cultural group to which the respondent or the respondent's ancestors belonged on first coming to this continent" (1981 census, cat. \#95-977, p. XI). This definition/question does not allow a 'subjective' definition which leaves it up to the individual to decide on his/her ethnic belonging, and does impose the state definition on the respondent. A 'subjective' definition which is based on the feelings of the respondent could have resulted in many more answering "Canadian" at the expense of, perhaps, the "British races" and perhaps, in fewer cases, the "French". These kinds of results may have had political implications which would not have favoured the "British races". Moreover, even the 'objective' definition is very biased. It excludes Canada as place of origin. In spite of this bias, there have always been some respondents who insisted that they were "Canadians" (see for example the 1931 census (V. 1, p. XVI) and 1971 census (cat. \#92-722, p. 18-19); in the latter, as many as 71,000 respondents insisted on being classified as Canadians. Interestingly, in the unpublished 1961 data about 'level of schooling' and education (which was obtained by the authors), there is a separate ethnic category labeled as "Canadian". This definition also excludes the United States of America as a 'place of origin', as the above definition is worded in regard to "coming to this continent" and not to this country! This bias favours mainly Americans who originated in Great Britain and are classified as "British".

The exclusion of Canada and the United States as places of origin started only in the 1871 Census. The Censuses for Lower and Upper Canada between 1842 to 1862 included these places. Interestingly, the categories of Upper Canada and/or Lower Canada and/or Canada were divided into "French Origin" and "Not of French Origin" (see Statistics Canada, 1666-1871: V. 4, pp. 137, 148, 166, $182-3,258,290-1)$.

The potential controversies about Census and ethnicity can have a political implication. For instance, at least in 1976, a multiple response in regard to mother tongue is regarded as "an error on the part of the respondent, (therefore) ... precedence was always given to English or French when these were reported with one or more non-official languages" (Demeres and Kralt, 1984: 11). A similar method that was used in the 1981 Census 'corrected' 87,000 responses in Quebec, and these 'corrections' were later found to be mostly errors which had discriminated against the political needs of the French speaking population of 
Quebec (Toronto Star, 29 May, 1986: A 18). The 1976 Census also manifests the possibility of mistakes in the coding and recoding of the data. Usually there are random errors at this stage, but in this case systematic errors occurred which inflated the rate of multiple response (Demeres and Kralt, 1984: 11). Another problem of this sort arises from the way ethnic groups have been clustered. For example, in 1921 "the Welsh" appeared as one of the "racial origin" groups and they "disappeared" later on; or "the Chinese" appear in some censuses separately and in others they disappear as part of "Asian groups". Moreover, at least in one case, a definition of an ethnic group was changed. The Census' definition of "the Jews", in 1971 only, was changed to include all the people whose religion was Jewish or whose ethnicity was Jewish (1971 Census, cat. \#92-922, p. 20). Here, political pressure led to change in the numbers of a specific ethnic group, but this example also manifests the tensions in regard to the meaning of the different definitions and numbers.

Statistics are, as we have argued throughout, socially constructed representations that confirms both notions of the valuable, the appropriate and the proper, and conform to viewpoints and values - perspectives and projections - outside those who named, mapped, sorted and categorized. They are social identifications, part of a compulsory I.D. that goes with 'belonging' to modern democratic nation-states (Corrigan and Sayer, 1985; Cohn 1986). To Cartograph, to Boundarise, to Number, to Account are features of both 'External' and 'Internal Colonialism' (Cohn and Dirks, 1986), that renders State-Knowledge.

\section{Re-using of Censal Data: Education, Ethnicity and Gender in Canada, 1921-1981}

In spite of these hard criticisms, still the Census data is the best data that can be used for national-historical comparison, as is done in this paper. The following section makes the best use we can of Censal data in a critical way. The remainder of this paper analyzes the educational achievement of gender and ethnic groups (separately and when possible together) since the Canadian Censuses began to supply information concerning both education and ethnicity in 1921. The historical information that can best provide a meaningful relative measure of the level of education of ethnic groups and also 'gender groups' in Canada is to be found in Statistics Canada's Census data ${ }^{6}$. In spite of all the above mentioned difficulties, the relative level of schooling of males and females and specific ethnic groups can be evaluated during the whole period of 1921-1981. In this paper partial demonstration of evaluation of the education indicators will be carried out in regard to males/females relative standing in educational achievement. This social representation will also be explored with regard to ethnicity. The average educational achievement of the total Canadian population will be reported and compared with 'highest' and 'lowest' ethnic group ranking, and with the two largest ethnic groups (according to the Census breakdown): "the British" and the 
"French". ${ }^{7}$ The comparison that is done in this paper is limited only to selective Census data between the years 1921 to 1981 (for more detailed comparison see Shamai, 1986b).

\subsection{Education and Ethnicity: Summarizing the 1921-1981 trend}

The 1931 Census is the first Census that included the "Indian and Eskimo", in the educational statistics. Table 74 in the 1931 Census concerns "school attendance of the Canadian-British and Foreign born population 7-14 years of age, by racial origin, months at school, and sex, Canada and provinces" (1931 census, V.1, p. 1160). For the total Canadian population among Canadian born, 93.03 percent are classifield as "at school". "The Jews" have the highest relative number of school attendants among Canadian born (97.4\%). They also have the highest relative number of pupils attending class in the "7-9 months" category, which is the longest time period reported in this table (96.44 percent compared to 89.51 percent of the total Canadian born population). The group that is doing the worst, in both categories, is again the "Indian and Eskimo": 8 of the "Canadian born'; only $65.0 \%$ attend school, and only $56.7 \%$ of pupil attend class in the "7-9 months" category.

The 1981 educational indicator is the highest level of schooling achieved (cat. \#92-914, Table 10). Among the total Canadian population not attending school, 15.32 percent have attained the (three) university levels, while 39.71 percent of "the Jews" have attained it. Again "the Jews" also have highest representation in two of the university levels (eighth, "without certificate" and tenth, "B.A.+"). "The Jews" have the highest representation, and they are the second group in the ninth level (with certificate). The "Asian groups" are the first in this level while second in the tenth level and third (after the "British and other" groups) in the eighth level. Again "the Jews" are leading and the "Asian groups" are following close behind. As was mentioned above, the percentage of the total Canadian population who have attained the three university levels, is 15.32 . The percentage of "British" in the same category is 16.88 (just above the average), and the percentage of "French" is 10.73 (again below the average). Again the "Native People" have the lowest representation in the highest educational levels: $4.76 \%$ have attained the three university levels, while only $1.35 \%$ have attained the highest level of "B.A. or higher degree" (compared to $26.2 \%$ of "the Jews"). 9

The trend over these 60 years is of dominance in educational attainment by the "Jewish" group and the "Asian groups". The combination of "Jews" and the "Asian groups" as the leading groups in education indicators is consistent. This is also consistent with the Toronto Board of Education findings of the "Every Student Survey" (the "Grade Nine students survey") which were published from 1980 to 1984. (Unfortunately the Board has ceased publishing these surveys since 1984.) These surveys cover a very short period, but because of their comprehensive coverage they can serve as an important indicator for gender and ethnic 
educational achievement 'gaps', and in this section the 'ethnic stratification' is being dealt with. ${ }^{10}$ The last study (Wright and Tsuji, 1984: 55) conducted in the fall of 1983 concludes:

students who identified themselves as Blacks are less likely to be studying at the Advanced level and the most likely to be taking Basic level courses ..., it can also be seen that the Native Canadian students are the least likely to be studying at the Advanced level and the most likely to be studying at the Basic level. As in previous years, the group with the largest proportion studying at the Advanced level are the "Asian" students. ${ }^{11}$

In fact, similar results are found in their previous surveys (1981 and 1982). The "Native people" are the most extreme example of this trend. ${ }^{12}$

The pattern that emerges points to the almost constant "educational achievement' pattern in Canada since 1921. ${ }^{13}$ The "Jews" and "Asian groups" in the top, the "British" around the average (in a declining trend), the "French" constantly below the average, and the "Native people" at the bottom. The 'mass education' of the population in the current century, did not help most of the Canadian population improve their relative standing (the "British" and the "French" compose about two thirds of the Canadian population). Moreover, educational inequality exists in regard to the total Canadian population: only $5.22 \%$ of the population 15 years and over obtain a Bachelor's degree; only $1.19 \%$ master's degrees, and only $0.30 \%$ a doctorate (1981 Census, cat. \#92-914, Table 4). Furthermore, when analysing these figures according to gender, the gap is even more overwhelming, as it is reported in the following sections.

\subsection{Educational facts and gender representation}

The following section points to the fact that in contrast to the popular myth that the education system is helping females to close the socio-economic gap between the sexes, the Canadian Census data indicates a more complex situation. This is confirmed by the Pineo and Goyder (1985) study based on 1981 Census data. They find that the probabilities of females proceeding to next level of schooling are higher in the lowest levels "but this educational advantage of females over males declines at ... higher educational levels. ... By the non-university postsecondary level ... onward males gain the advantage over women" (pp. 15-18). These differences are found to be statistically highly significant (ibid., p. 18). Thus, Pineo and Goyder state: "we conclude that, on balance, the Canadian educational system acts more ascriptively upon women than on men" (p. 19) (cf. Corrigan, 1977; 1986b).

Again, this article points only to some examples (for more detailed information see Shamai, 1986b). As far back as the 1921 Census (the first Canadian Census to supply information with regard to ethnicity and education), the figures which use illiteracy rates as an educational indicator, point to an important finding: $5.17 \%$ of the males are illiterate, while only $3.75 \%$ of the females are illiterate. The difference in illiteracy rates between the sexes among the Canadian born is even 
higher: $4.13 \%$ males vs. $2.57 \%$ females! The 1931 Census show similar trend: $3.94 \%$ of the males vs. $2.76 \%$ of the females are illiterate. Among the 'Canadian born': $3.27 \%$ males vs. $1.87 \%$ females are illiterate.

The 1941 Census supplies an important comparison (V. I; Tab. III, p. 314), with regard to "percentage of the population at each schooi age, attending school, by sex, for Canada, 1921-1941" (the Table did not include the Yukon and Northwest Territories). It is obvious from the numbers that the same pattern exists in these three Censuses.

The 1941 Census explanations for the above trend are 'biological' and somewhat 'bizarre'. ${ }^{14}$ The data points to the fact that the males have somewhat higher representation in the lower age groups of school age, and have about twice the percentage of females in the highest age group reported: $20-24$ years, which are mainly the postsecondary age group (and not as the Census commentary tries to convey as 'retarded high school boys').

The 1981 Census reports on population 15 years and over (in different publications) attending and not attending school, by highest level of schooling and sex. With regard to the lowest categories of years of schooling, not only is 'relative improvement' of the males continuing, but the males have a smaller representation in these categories. With respect to population not attending school (Vol. 1, cat. \#92-914, Table 2) the males for the first time do not have relatively a higher representation in the lowest categories of years of schooling: in the "less than grade 5 ' category the "Ratio" is 0.9 . For every 1 percent of females in these categories there is only 0.9 percent of males. With regard to the population attending school full-time, in the 'less than grade 5' category, (ibid) both sexes had almost the same relative presentation, but for the first time the males had slightly less representation. The gender "Ratio" is 1.0 (or more exactly 0.99 ). For the category "less than grade9', (attending and not attending school 15 years and over), (ibid, Table 1), for the total Canadian population and the "urban' Canadian population, the "Ratio" is again slightly less than $1(0.96)$, while for the "rural' population, the "Ratio" is still above 1 (relatively more males than females): it is 1.2 .

Because the differences are so small there is a need to report to the second decimal point of the "Ratio". All these "Ratios", however, point to the dramatic change in the lower educational achievement levels in 1981: the males 'broke away' more rapidly than the females from these categories, a fact that is overlooked in the current literature, which focuses more on the highest levels of schooling, which in 1981 include close to 4 million Canadians (Shamai, 1986b).

The various Census educational indicators and the Toronto Board of Education 'Every Student Survey', which provides different information on educational achievement, are consistent: wherever the females have been better than males, the males have tended to close the gap or even reverse the situation. Wherever the males have been better than females, the gap has been closed slowly, if at all.

Even when the females somewhat reduced the gap, in the top educational levels, probing the meaning of these numbers can manifest how limited that reduction is. 
According to Statistics Canada, (1985, Table 9) in 1971, 2.9\% of the female, and $6.2 \%$ of the male population 15 years and over have a 'university degree'. In 1983 , $7.7 \%$ of the females and $11.3 \%$ of the males are classified in the same category. Thus, while the relative gap decreased the absolute gap still increased. In a more detailed examination of the highest level of schooling, doctoral degrees, the situation is also similar to previous findings. Although, the fact that among "Doctoral Degrees Granted by Field of Study, 1971 and 1982", (ibid, Table 6) the gap of the total doctoral degrees is largely reduced (the 1971 "Ratio" is 9.7 and the 1982 "Ratio" is 3.0), in regard to the different sort of the "fields of study' the situation is the reverse, the "Ratio" in the "mathematics and physical sciences" fields increased from 1.4 in 1971 to 2.6 in 1982, while the "Ratio" in the 'education' field decreased from 3.0 in 1971 to 0.6 in 1982. On the other side of the educational achievement ladder of 'labour force participation rate' of 'less than grade 9' 'educational attainment' in 1982 (ibid, Table 11), 58.5\% of the males while only $25.6 \%$ of the females took part in the paid labour force. Thus, the trend is favoring again and again the males, as the Census finds: "The average earning of women are well below those of men at all education levels" (ibid, p. 26).

\subsection{Ethnicity, gender, and educational achievement in Canada: discussion ${ }^{15}$}

The above conclusion means that if the situation continues 'unchanged' the females will not benefit - in proportion to their numbers - from the Canadian education system. The move towards urbanization and modernization should be probed in a much more critical view than it is currently examined, in view of these dramatic findings. In Canada, "Poverty Profile 1985" (National Council of Welfare, 1985) stresses the importance of exactly these variables: education, gender, and urbanization in relation to the socio-economic status of the Canadian people. "The lower the education ... the greater the chance of failing below the low-income line" (p. 36). "Four in ten families headed by women are poor, compared to only one in ten by men" (p. 16). The data also points out that in urban areas "the poverty rates have climbed steadily since 1980 " (p. 33) and in higher rates than the rural areas (see Tables 17 and 18). The "1986 Poverty Lines" (National Council of Welfare, 1986) of Canada, confirm the above findings, and adds that "six in every ten women under age 65 who are single parents raise their children on an income below the poverty line" (p. 6). Recent data from the United States of America confirms the importance of female-gender, non-white ethnicity and low educational achievement in relation to poverty (cf. New York Times, 21, October 1986, pp. 1, 15; Time, November, 3, 1986, pp. 54-55). All that coincides with one of the conclusions of a study by Statistics Canada which was based on 1981 Census data: "birth and initial circumstances of an individual are important factor towards one's economic position" (Globe and Mail, July, 9, 1986, p. A 10; cf. Statistics Canada, 1985).

The most striking fact that emerged from the Census is reported in the 1921 Census (Vol. 4, p. XVI, Table VII): of the females "gainfully employed 10 years 
of age and over, by occupational groups, for Canada" $24.2 \%$ were classified as 'professional'. Pineo et al (1977) provide the last similar data available, based on 1971 Census data and found that only $22.3 \%$ of the females belonged to the 'upper white collar' group (p. 95) (which included the expected top seven major "socio-economic categories": self-employed professionals; empioyed professionals; high level management; semi-professionals; technicians; middle management; and supervisors). Thus, from 1921 to at least 1971 the trend - with regard to the very important occupational/socio-economic status - shows that the women's position at least did not improve, and possibly even worsened. The situation with regard to Native people is even more negative: thus, in a recent Federal study (by the Department of Health and Welfare) "only 200 out of 325,000 qualified health professionals surveyed had native ancestry" (University Affairs, November, 1986, p. 12). The historical systematic discrimination against Native people and other powerless ethnic groups in the Canadian society is documented in Palmer, 1976 and with regard to the Canadian education system in Jaenen, 1973.

The pattern from 1921 to 1981 revealed in this article stresses the following features: (1) two of the three 'founding people' ('British' and 'French') are located in the middle range; (2) other groups are more polarized: Chinese and Jews, among others, are located in the upper range, whilst the 'Blacks', among others, are located below the average, with the first 'founding people' - 'Native' peoples - at the bottom (cf. Burnaby, 1982, 1983; Allison, 1983). This pattern constantly appears as a 'new' phenomenon and questions regarding the 'failure' of groups located in the lower ranges appear in the representations of academic (as in Porter et al, Stations and Callings, 1982, p. 315), educational policy-makers and social planners (as in the "Bovey commission", 1984, p. 8f; and Towards the Year 2000, 1984), or in the public domain (for example the front page story in the Globe and Mail, Sept, 14, 1985: "Blacks and Schools, who fails?"). It is also reflected in the "Equality Now" (1984) report, which states that the 'visible minorities' are faced with a number of obstacles to participation in postsecondary education (p. 133). This report also points to the ethnic streaming process and points to their "social and cultural adjustment problems (in education)" (p. 124: for the United States see New York Times, 19 April, 1987: 1,18). Moreover, according to the recent Report of the Commission on Private Schools in Ontario (Oct, 1985) by Dr. B.J. Shapiro, some "groups have often been able to use the public schools to perpetuate racial, class and religious discrimination" (p. 59). These ideas are also echoed by Richmond (1980).

The conventional ethnic (i.e. pluralism or multiculturalism, see Mazurek 1987) and educational ideologies and theories fail to explain this sort of "ethnic streaming", and even the concepts from the "new sociology of education" are only partly useful in explaining this phenomenon (Shamai, 1987). However, the new sociology of education's emphasis on the relative importance of schooling can supply an important clue for explaining this phenomenon. In this case though, it is not the usual explanation of control of society by its dominant groups. Rather, the explanation lies in the differential culture, value, beliefs and historical experience 
of the ethnic groups, and in the way each is materialized in the attitudes of the students' family and community towards education and schooling. A similar explanation was reached in regard to the high achievement of the Chinese in the United States (Ogbu, 1983; 189-190). According to Ogbu's (1978) typology, the "Jews" are an "autonomous minority". One of the traits of an autonomous minority is that: "members of autonomous minorities do not necessarily regard the majority group as their reference group, nor do they necessarily want to be assimilated" (ibid. p. 23). Hence, the "Jews" manage to go through the educational system, but without using all its moral-value standards as totally their own moral values. The "Jews" use the parts of the educational system that fit their needs: they "know the ruling ecology" (using Corrigan's, 1986b, words; and cf. Corrigan 1981; 1986a; 1986b; and 1987); and they ignore the parts that contradict or do not fit their beliefs. It seems that the influence of family, community and ethnic identity is much more important to them than the influence of the public schools. This points to the need to further probe the sources of influence on the student, particularly in regard to the family, and the (public/private) school. The "Jewish" and "Chinese" educational achievements in seven Censuses in sixty years serves to reinforce the notion that the family and ethnic/religious values are the most important sources of socialization. However, the failure of "Native people" one of the "Founding peoples" of Canada, is related to variety of historical, sociological, economic and educational conditions, which all managed to exploit and marginalize these people. In order to change this situation there is a need to change their position with regard to the rest of Canadian society.

This article is based on critical analysis of statistical data. In order to probe this data there is a need to be aware of the biases. This article points to several biases in the data and then uses the Censal data for historical comparison. Using the data in a critical way can lead to interesting results, as it is done in this article. The numbers can sometimes cover different situations, however, uncovering the situation behind the numbers is not an impossible task. This process may yield different crucial 'social facts' as it was demonstrated in the case of educational achievement, ethnicity and gender in Canada.

\section{Acknowledgments}

We acknowledge the financial help of Health and Welfare, Canada: Demographic Review Project - Phase 1 .

\section{NOTES}

${ }^{1}$ Statistics Canada (Demeres and Kralt, 1984) exemplifies a possibility of bias in this stage, in regard to hostility against Germany and the German language around the 1940's: "It can therefore be expected that there was an underenumeration of the (German speaking) population" (p. 9).

\footnotetext{
${ }^{2}$ This is again being confirmed by the latest (1986) Canadian Census where the unpaid domestic labour, typically that done by women, is consistently being denied (see 1986 Census questionnaire and the attached Guide-book for households).
} 
${ }^{3}$ Notice that the gender is only masculine; for discussions of 'literacy' in relation to women see Rockhill, 1987.

${ }^{4}$ Note that "British born" are not regarded as "Foreign born"!

${ }^{5}$ Adamson (1984: 14) points to a similar phenomenon, of "English favour" presentation of figures, in history books in Ontario schools in regard to English and French Canadians who volunteered for military service in the First World War.

${ }^{6}$ The validity of this study can be confirmed by similar studies, which are based on Census data such as Mare (1979), Pineo and Goyder (1985); Porter (1965) Vertical Mosaic, O'Bryan, Reitz and Kuplowska (1976), and Reitz (1980).

${ }^{7}$ For more detailed account of the "French" educational achievement in Canada in general and Ontario in particular see Carrier, 1985; Cachon, 1986; and Churchill, Frenette and Quazi, 1985.

${ }^{8}$ The data excludes the Northwest Territories and the Yukon (ibid), thus, the situation of the Native people could be even worse than the gloomy situation presented here.

9The situation in Metropolitan Toronto in regard to the "Jewish" population is similar. Here, we find that 21.5 percent of the Jewish population obtain a university degree (including 0.9 percent doctoral recipients), compared with 8.6 percent (including 0.3 percent doctoral recipients), of the non-Jews (Shamai, 1986a: ch. 4; Shamai, 1986b).

${ }^{10}$ The category of Jewish students has never been included in this study.

${ }^{11}$ This category aggregates very different groups, for example Bangladesh students are less likely to be in the 'Advanced level' compared with Japanese, Chinese or Koreans.

${ }^{12}$ Interestingly the "Black" category has not been reported in the Canadian Censuses, at least in regard to education indicators, since 1931. Thus, this group throughout Canada may also be in a similar situation to those reported in Toronto (cf. Globe and Mail, 14 Sept, 1985; and Head and Lee, 1975 and 1979-80).

${ }^{13}$ Historians have examined earlier censuses, as far back as 1871 to show the significance of 'Ethnicity' in the formation of Canadian society (see Darroch and Ornstein, 1980; cf. Young, 1987; Corrigan, 1986a). This approach is being focussed in the SSHRCC funded State Formation Project, (co-ordinated by Professors Corrigan and Curtis) which examines ethnicity in relation to the formation of the Canadas from the early 1800s, cf. Corrigan and Curtis, 1986; Corrigan, Curtis and Lanning, 1987). Similarly, with regard to England it was done by Corrigan and Sayer (1985).

${ }^{14}$ The Census commentary reads:

This is probably related to the observed fact that girls tend to mature more rapidly than boys. ... This [data] probably reflects a tendency for more girls to be accelerated or to receive double-promotions, and for the boys to be retarded and to complete high school at a somewhat higher age (ibid).

However, the Census commentary acknowledge (p. 314) that "in the upper age group [20-24 years] the majority have been eliminated by competitive examination" which no doubt favored the males (cf. Walden and Walkerdine, 1982; Walkerdine, 1984, 1987).

${ }^{15}$ For complementary analyses of Ontario see Kodikara, 1986; and Gorman, 1987. 
I. Appendix A: Proportion of Population 5-24 Years Attending School Full-time, by Age and Sex, Canada, 1921-1971.

Chart - 1

Proportion of Population 5-24 Years Attending School Full-time,

Graphique -1 by Age and Sex, Canada(1), 1921-1971

Proportion de la population âgée de 5 à 24 ans, tréquentant l'école à plein temps,

selon l'âge et le sexe, Canada (1), 1921-1971

$\%$

90

5.14

Groupe dàge

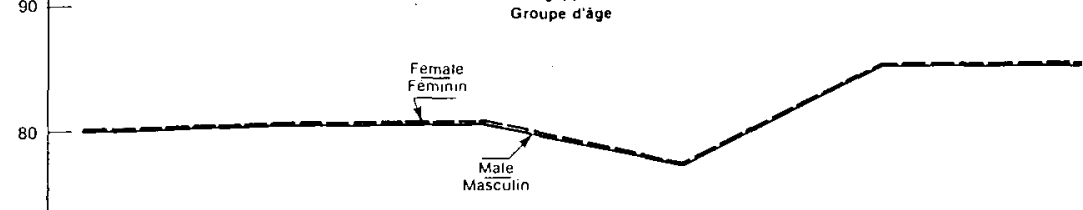

70

60

$-$

Masculin

6

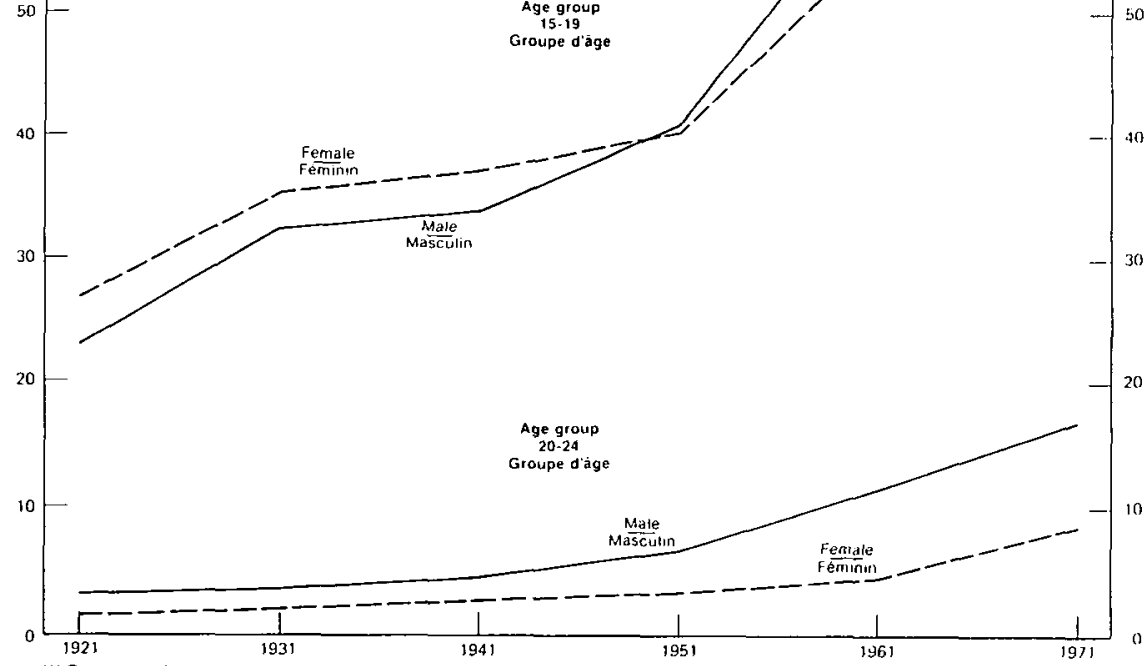

Groupe d'àge

(1) Percentages lor the census of 1921 does not include Newtoundiand, Yukon and Nor thwest Terrliorles - Les pourcentages pour le recensement de 1921 n'incluent pas Terre-Neuve, te Yukon el lés Territores du Nord-Ous:5t.

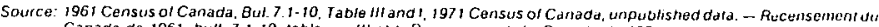

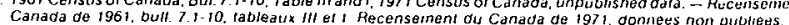

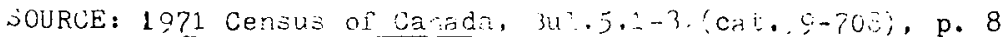




\section{BIBLIOGRAPHY}

Abrams, P. (1977) "Notes on the Difficulty of Studying the State". Paper presented at the British Sociological Association Conference.

Adamson, A. (1984) "Canadian Studies, Fantasyland North". Mudpie 5 (10).

Allison, D. (1983) "Fourth World Education in Canada and the Faltering Promise of Native Teacher Programs." Journal of Canadian Studies, 18 (3), pp. 102-118.

Armstrong, P. \& Armstrong, H. (1983) "Beyond Numbers: Problems with Quantitative Data". Alternate Routes, 6, pp. 1-40.

The (Bovey) Commission on the Future Development of the Universities of Ontario: Ontario Universities: Options and Futures (1984), Toronto.

Bumaby, B. (1982) Language in Education Among Canadian Native Peoples. Toronto: The Ontario Institute for Studies in Education.

Burnaby, B. (1983) "Native Education: The Needs of a Minority Culture Within a Monolith". Multiculturalism, 6, pp. 11-13.

Cachon, J. C. (1986) Etude Stratégique sur les services d'Education universitaire en français dans le Nord-est de l'Ontario. Sudbury, L'Université Laurentienne.

Carrier, D. (1985) L'Université d' Ottawa et la francophonie ontarienne: rapport du groupe de travail sur les services universitaires en français. L'Université d'Ottawa.

Churchill, S., Frenette, N. \& Quazi, S. (1985) Services et besoins éducatifs des Franco-Ontariens. Toronto: Ministère de l'Education.

Cohn, B. (1986) "Language of Command and Command of Language". Subaltern Studies, (6).

Cohn, B. \& Dirks, N. (1986) "Culture and Colonialism: Deployments of Power and Resistance". Paper presented at the Mellon Symposium on State Formation and Colonization, Pasadena, California, April-May 1987.

Corrigan, P. R. D. (1977) "Feudal relics or Capitalist monuments? Notes on the Sociology of Unfree Labour". Sociology, 11, pp. 435-463.

Corrigan, P. R. D. (1981) "On Moral Regulation" Sociological Review, 29, pp. 313-331.

Corrigan, P. R. D. (1986a) "Race/Ethnicity: Embodying Differences Educationally”. In J. Young (ed.) Breaking the Mosaic. Toronto: Garamond, 1987.

Corrigan, P. R. D. (1986b) "Hiding the Hidden Curriculums/Finding the Social Classification". Paper presented at the "Ministerial Conference", Toronto: March 19-21, 1986.

Corrigan, P. R. D. \& Sayer, D. (1985) The Great Arch: English State Formation as Cultural Revolution. Oxford, New York: Basil Blackwell.

Corrigan, P. R. D. \& Sayer, D. (1987) "From the Body Politic to the National Interest". Keynote Address, the Mellon Symposium on State Formation and Colonization, Pasadena, California, May, 1987.

Corrigan, P. R. D. \& Curtis, B. (1986) "Education, State Formation, Inspection" Canadian Historical Association Papers, pp. 156-171.

Corrigan, P. R. D., Curtis, B. \& Lanning, R. (1987) “The Political Space of Schooling”. In T. Wotherspoon (ed.) Political Economy of Canadian Schooling. Toronto: Methuen, pp. $21-43$.

Cullen, A. J. (1975) The Statistical Movement in Early Victorian Britain. Harvester.

Darroch, A. G. \& Ornstein, M. D. (1980) "Ethnicity and Occupational Structure in Canada in 1871: the Vertical Mosaic in Historical Perspective". Canadian Historical Review, 61 (3), pp. $305-333$. 
Demeres, L. \& Karlt, J. (1984) On the Comparability of the Census Mother Tongue Data, 1976-1981, Working Paper (Technical). Ottawa: Statistics Canada.

Donald J. (1979) "Green Paper: Noise of Crisis". Screen Education (30).

Durkheim, E. (1912) Elementary Forms of Religious Life. Allen \& Unwin.

Equality Now. Report of the Social Committee on Visible Minorities in Canadian Society. (March 1984). Hull, Quebec. Supply and Services Canada.

Foucault, M. (1981) "Questions of Method". Ideology and Consciousness (8).

Foucault, M. (1982) "The Subject and Power". Critical Inquiry (8).

Globe and Mail, (14 September, 1985) "Blacks and Schools".

Globe and Mail, (9 July, 1986) "Wives' Pay Swells Top Income Bracket".

Gorman, C. M. (1987) The Strategic Planning Process in the Ontario Ministries of Education, a Sociological Investigation. M.A. Thesis, Graduate Department of Education, University of Toronto

Hakim, C. (1980) "Census Reports as Documentary Evidence: The Census Commentaries 1801-1951". Sociological Review, 28(3), pp. 551-580.

Head, W. \& Lee, J. (1975) The Black Presence in the Canadian Mosaic. Toronto: Human Rights Commission.

Head, W. \& Lee, J. (1979-80) "The Black Presence in the Canadian Mosaic: Discrimination in Eduçation". Interchange, 9(1), pp. 85-93.

Henriques. J. (1984) "Social Psychology and the Politics of Racism". In J. Henriques et al (eds.). Changing the Subject. London and Toronto: Methuen, pp. 60-89.

Jaenen, C. J. (1973) "Minority Group Schooling and Canadian National Unity". The Journal of Educational Thought, 7(2), pp. 81-93.

Kodikara, A. (1986) "Schooling, Politics and the State". Ph.D. Thesis, University of Toronto.

Mare, R. D. (1979) "Changes and Stability in Educational Stratification". American Sociological Review, 46(1), pp. 72-87.

Mazurek, K. (1987) "Multiculturalism, Education and the Ideology of the Meritocracy". in T. Wotherspoon (ed.) Political Economy of Canadian Schooling. Toronto: Methuen. pp. 117-140.

National Council of Welfare (1985) Poverty Profile-1985. Minister of Supply and Services.

National Council of Welfare (1986) 1986 Poverty Lines. Minister of Supply and Services.

New York Times (21 October, 1986) "New Jobs in Cities Little Aid to Poor", pp. 1-18.

New York Times (19 April, 1987) "Enrollment of Minorities In Colleges Stagnating", pp. 1-15.

$\mathrm{Ng}$, R. \& Estable, A. (1987) "Immigrant Women in the Labour Force: an Overview of Present Knowledge and Research Gaps". Resources for Feminist Research, 16(1).

O'Bryan, G., Reitz, J. G. \& Kuplowska, O. (1976) Non-Official Languages: A Study in Canadian Multiculturalism. Ottawa: Supply and Services Canada.

Ogbu, J. V. (1978) Minority Education and Caste. N.Y.: Academic Press.

Ogbú, J. V. (1983) "Minority Status and Schooling in Plural Societies". Comparative Education, 20(2), pp. 168-190.

Palmer, H. (1976) "Reluctant Hosts: Anglo-Canadian Views of Multiculturalism in the Twentieth Century". In Multiculturalism as State Policy. Second Canadian Conference on Multiculturalism, pp. 81-110.

Perkins, T. (1979) "Sterotypes", in M. Barrett and others (eds). Ideology and Cultural Production. London: Groom Helm. 
Pineo, C. P. \& Goyder, J. (1985) Growth of the Canadian Education System: an Analysis of Transitional Probabilities. Hamilton, Ont.: Quantitative Studies in Economics and Population Research Paper No. 187, McMaster University.

Pineo, C. P., Porter, J. \& McRoberts, H. A. (1977) "The 1971 Census and the Socioeconomic Classification of Occupations". Canadian Review of Sociology and Anthropology, 14(1), pp. 91-102.

Porter, J. (1965) The Vertical Mosaic. Toronto: University of Toronto Press.

Porter, J., Porter, M. \& Blishen, B. (1982) Stations and Callings: Making it Through the School System. Toronto: Methuen.

Radical Statistics Education Group (1982) Reading Between the Numbers: a Critical Guide to Educational Research. London: BSSRS Publications Ltd.

Reitz, J. G. (1980) The Survival of Ethnic Groups. Toronto: McGraw Hill Ryerson.

Report of The Commission on Private Schools in Ontario. (By Dr. B. J. Shapiro), (1985) Toronto: Government of Ontario.

Richmond, A. H. (1980) Factors in Adjustment of Immigrants and their Descendants. Ottawa. Ministry of Supply and Services.

Rockhill, K. (1987) "Gender, Language and the Politics of Literacy". British Journal of Sociology of Education. (Forthcoming).

Sayer, D. (1987) The Violence of Abstraction. Oxford; Blackwell.

Shamai, S. (1986a) Ethnic and National Identity among Jewish Students in Toronto. Unpublished Doctoral thesis, Department of Education, University of Toronto.

Shamai, S. (1986b) "Ethnicity, Gender and Educational Achievement in Canada, an HistoricalStatistical Analysis, Based on Censal Data, 1921-1981". Occasional Papers in Critical Sociology, (1). Toronto: Department of Sociology in Education. Ontario Institute for Studies in Education.

Shamai, S. (1987) "Critical Theory of Education and Ethnicity: the Case Study of the Toronto Jewish Community". Journal of Education, 169(2), (Forthcoming).

Smith, D. (1987) The Social Organization of Knowledge. (Forthcoming).

Statistics Canada (1929) Origin, Birth Place, Nationality and Language of the Canadian People. (A Census Study based on the Census of 1921 and Supplementary Data.) Ottawa: F. A. Acland, Printer to the King's Most Excellent Majesty.

Statistics Canada - Census of Canada, 1666-1871.

Statistics Canada - Censuses of Canada; from 1921 to 1981.

Statistics Canada (1985). "Women in Canada - A Statistical Report". Minister of Supply and Services Canada. (Cat. 89-503E).

Time (November 3, 1986), "Is the Middle Class Shrinking?"

Toronto Star (29.5.1986). "Even Census Can Fuel the Language Debate in Quebec."

Towards the Year 2000: Future Conditions and Strategic Options for the Support of Learning in Ontario. Ontario Ministry of Education and the Ministry of Colleges and Universities. Review and Evaluation Bulletins, v. 5(1), 1984.

University Affairs (November, 1986).

Walden, R. \& Walkerdine, V. (1982) Girls and Mathematics: the Early Years. London: University of London Institute of Education.

Walkerdine, V. (1984) "Developmental Psychology and the Child-Centred Pedagogy: the Insertion of Piaget into early Education". In J. Henriques (ed). Changing the Subject. London: Methuen, pp. 153-202. 
Walkerdine, V. (1987) The Mastery of Reason (2V). Methuen, 1987.

Williams, L. (1986) "Families and the Canadian Census: a Brief Critique of Current Methodology and Some Suggested Improvements". Occasional Papers in Social Policy Analysis (4). Toronto: Department of Sociology in Education. Ontario Institute for Studies in Education.

Wright, N.E. \& Tsji, G. K. (1984) The Grade Nine Student Survey: Fall 1983. Toronto: Toronto Board of Education, Research Department.

Wrong, D. H. (1959) "Ontario Jews in the Larger Community". In A. Ross (ed.). A People and lts Faith. Toronto. University of Toronto Press, pp. 45-47.

Young, J. (1987) (ed.) Breaking the Mosaic. Toronto: Garamond.

\section{This Publication is available in Microform.}

\section{University Microfilms International}

Please send additional information

for

Name

Institution

Street

City

State Zip

300 North Zeeb Road. Dept. P.R., Ann Arbor. Mi. 48106 